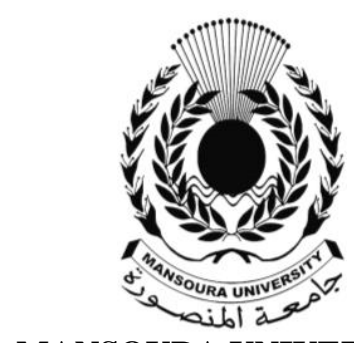

MANSOURA UNIVERSITY

FACULTY OF ARTS

\title{
The Stela of Snefer
}

(u)

Présenté par

\section{Hala Mahmoud Khalaf}

Associate Prof.of Ancient History

Faculty of Education

Ain Shams University

Journal of The Faculty of Arts- Mansoura University

$62^{\text {st }}$ ISSUE- JUN. 2018 


\title{
Hala Mahmoud Khalaf \\ Associate Prof.of Ancient History \\ Faculty of Education \\ Ain Shams University
}

\section{The Stela of Snefer (u)}

\begin{abstract}
During his work at Abydos August Mariette excavated the cemetery of the Middle Kingdom, he found many stelae dating back to that period, and these stelae were kept in Boulaq Museum before moving to the Egyptian Museum. Some of these stelae were published and some still not been published. The present study deals with one of the Abydos Stelae to reveal its contents, typology and Date.

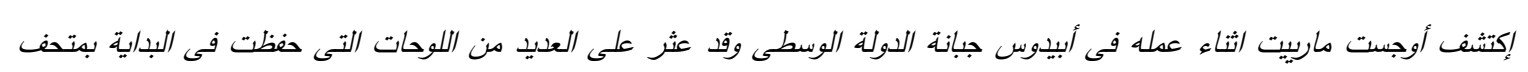

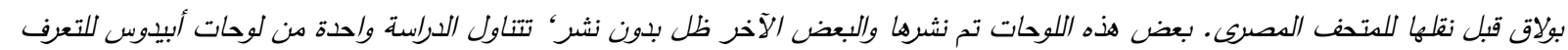

$$
\begin{aligned}
& \text { على محتو/ها وطرازها وتاريخها. }
\end{aligned}
$$$$
\text { Key Words }
$$

Stela- Abydos-Snefer(u)-offering-Osiris- Hetepet- Aa Amun - Kha Kaw- Itut- Wadjet-Inpw nekht

$$
\text { لوحة- أبيدوس - سنفر (و) - قرابين -أوزيريس- حتبت-عا آمون - خع كاوو - إيتوت- واجيت- إنبو نخت }
$$

Abydos was a sacred city in Ancient

temenos; graffiti from the temple of Sety. London.; Id. 1909. Excavations at Abydos, 1909: preliminary description of the principal finds. Annals of Archeology and Anthropology 2, 125-129; Petrie, W. M. F. 1900-1901. The royal tombs of the First Dynasty, 3 vols. Memoir of the Egypt $==$ Exploration Fund 18. London

${ }^{4}$ cf.Baines, J. 1990. Recording the temple of Sethos I at Abydos in Egypt. Bulletin of the Ancient Orient Museum 11, 65-95; Id. 2001. Colour use and the distribution of relief and painting in the Temple of Sety I at Abydos. In Davies, W. V. (ed.), Colour and painting in ancient Egypt, 145-157. London:British Museum Press; Brand,P.J.2000. The monuments of Seti I: epigraphic, historical and art historical analysis. Probleme der Ägyptologie 16. Leiden.; Calverley, A. M. and Myrtle F. B. 1933-1958. The temple of king Sethos I at Abydos, 4volumes: I: the chapels of Osiris, Isis and Horus. II : the chapels of Amen-Ré', = Re'-Harakhti, Ptah, and King Sethos. III: the Osiris complex. IV: the second hypostyle hall. Chicago.; Frankfort, H.1933.The cenotaph of Seti I at Abydos. 2 vols. London: Egypt Exploration Society; Sawy, A. el- 2003. A new discovery at the Sety I temple in Abydos. In Hawass, Zahi and Brock, L. P. (eds), Egyptology at the dawn of the twenty-first century: proceedings of the Eighth International Congress of Egyptologists, Cairo, 2000 1, 424-431. Cairo; New York: American University in Cairo Press; Murray, M. A. 1904. The Osireion at Abydos. British School of Archaeology in Egypt and Egyptian Research Account [9] (9th year). London.
Egypt. The principal deity of Abydos was called Khentyamentyu 'foremost of the Westerners'; by the First Intermediate Period this god had been identified with Osiris who replaced oldest worship of the jackal god Wepwawet. ${ }^{1}$

It was occupied since the Predynastic period $^{2}$ to the Roman period. It includes Cemeteries $^{3}$, temples ${ }^{4}$ and towns. ${ }^{5}$

${ }^{1}$ cf. O'Connor, D. 2009. Abydos: Egypt's first pharaohs and the cult of Osiris. New aspects of antiquity. London.

${ }^{2}$ cf.Bestock, L. 2011. The first kings of Egypt: the Abydos evidence. In Teeter, Emily (ed.), Before the pyramids: the origins of Egyptian civilization, 137144. Chicago.; Dreyer, G.2011. Tomb U-J: a royal burial of Dynasty 0 at Abydos. In Teeter, Emily (ed.), Before the pyramids, 127-136. Chicago.; Stevenson, A. 2009. The predynastic cemeteries of Abydos. Egyptian Archaeology 34, 25-26

3 cf.Naville, E.1914. The cemeteries of Abydos. Part I: 1909-1910. The mixed cemetery and Umm el-Ga'ab. Memoir of the Egypt Exploration Fund 33. London.; Peet, T. E.1914. The cemeteries of Abydos. Part II: 1911-1912. Memoir of the Egypt Exploration Fund 34. London.; Id. and Loat, W. L. S. 1913. The cemeteries of Abydos. Part III: 19121913. Memoir of the Egypt Exploration Fund 35. London.; Garstang, J. 1901. El Arábah: a cemetery of the Middle Kingdom; survey of the Old Kingdom 
Lieblein,J. 1892, Hieroglyphisches NamenWörterbuch, Leipzig , Nr.1823.

Lange,H.O. and Schäfer, H. (1902-25)

Grab und Denksteine des Mittleren Reiches,I-IV vols,(CCGNos.20001-20780), Berlin

\section{Description}

It is a rectangular painted limestone stela formed in the shape of a false door with a cornice on the upper part with reeds decoration ${ }^{(a)}$, below it is a torus surrounded the stela from its sides, the bottom of the stela represented by three wide lines red, yellow and blue.

The scenes and texts depicted on first part the stela show the owner of the stela named Snefer $(u)^{8}$ on the left side is sitting on a chair with low back while its legs represent the lion legs, there is an ointment jar under the chair. The deceased smells a lotus flower while in front of him is an offering table with loaves of bread under it there are bow of bread and two vessels surmounted with lotus flower followed by the inscriptions indicate a thousand of bread and a thousand of beer jar

In front of the offering table there are two members of Snefer $(u)$ 's family his son Aa Amun wearing a short kilt and a scarf on top of his chest, he holds a papyrus roll in one hand while

raising the other hand in a priestly attitude doing an offering formula according to the accompanying text. The wife Hetepet stands at the end of the scene wearing a long tight dress and smells a lotus flower.

The second part of the stela shows from right to left the son of the deceased standing facing the other members of the family; he holds a lotus flower in one hand while he holds a kerchief in the other hand and wearing a short -wide kilt while a wide collar on his neck and scarf on his chest. The three persons on the left side begin with another son facing the first one; he holds a lotus flower in one hand while he holds a kerchief in the other hand and wearing a

${ }^{8}$ PN I, p.315,no. 13
The sacred city of Abydos was including Umm el-Qa'ab, a royal necropolis where early pharaohs were buried.

The cemetery of officials began during the first dynasty; It was enlarged in the twelfth and thirteenth dynasties and a large number of tombs from eighteenth to twentieth dynasties, and was still in use until Roman times. ${ }^{6}$

By the time of Middle Kingdom (about 2025-1700 BC) one of the First Dynasty royal tombs was seen as the tomb of Osiris. It became desirable to be buried near to the god or on the processional way, for that purpose many officials had chapels set up with one or more stelae, many hundreds of funeral stelae were found by Mariette's workmen. ${ }^{7}$

The stela of Snefer(u)

Registration numbers: CCG 20128; SR3/9606 room 21*

Measurements: height $31 \mathrm{~cm}$ and width $23 \mathrm{~cm}$

Provenance: Abydos, north cemetery Bibliography:

Marriette, A.1880, Catalogue General des Monuments d'Abydos decovert pendant les fouilles de cette ville, Paris, p.341, Nr.953.

5 cf.Petrie, W. M. F. , Ayrton, E. R. Currelly, C. T. and Weigall, A. E. 1902-1904. Abydos, 3 vols. Memoir of the Egypt Exploration Fund 22; 24. London.; Randall-MacIver, D. and Mace, A. C. 1902. El Amrah and Abydos, 1899-1901. London: Egypt Exploration Fund.

6 cf. Snape, S. 1986. Mortuary assemblages from Abydos. D.Phil thesis, University of Liverpool; Von Beckerath, J.1975, "Abydos" in: L̈̈ I, Wiesbaden, cols. 28-42

7 Marriette, A. 1880, Abydos: description des fouilles: Temple de Séti (Supplément). Temple de Ramsès. Temple d'Osiris. Petit Temple de l'Ouest. Nécropole, Vol. II, Paris, p.42; PM V,pp.56$58,263 \mathrm{ff}$.

*I'd like to thank Miss Sabah Abdel Razig the general Director of the Egyptian Museum, Dr Lotfy Abdel Hamid, the Director of the Egyptian Museum, Mrs Rania Diaa, Miss Marwa Bader el din from EMC_RCMDD and the photographer Ahmed Amin. 
Line1- Htp -(r)di(w)- nswt PtH \%kr di=f prt xrw t Hnqt

The offering which the king has given ${ }^{9}$ and/to Ptah and Sokar,may he gives invocation with bread,beer,

Line 2- kAw Apdw Ss mnxt snTr n kA n $\%$ nfr(w)

Oxen, birds, alabaster, linen and incense to the ka of Snefer $(u)^{10}$

$\mathrm{B}$-under the offering table

xA t xA Hnqt

A thousand of bread and a thousand of beer

$\mathrm{C}$-on top of the wife of the owner stela and his son

Line 1- Hmt=f mrt=f nbt pr @tpt mAat xrw imAx (wt)

His wife his beloved the mistress of the house $^{(b)}$ Hetepet ${ }^{11}$ the justified, the revered one

Line 2-irt Htp -(r)di(w)- nswt in $\mathrm{sA}=\mathrm{f}$ mry=f aA-imn

Doing the offering formula by his son, his beloved Aa-Amun ${ }^{12}$

$\mathrm{D}$ - on top of the son on the left side

Htp -(r)di(w)- nswt Ra n kA n sS \#a kAw

The offering which the king gives and

Re to the ka of the scribe

Kha-Kaw $^{(c) 13}$

E- on top of the two ladies on the left side

Htp -(r)di(w)- nswt n kA n nbt pr Itwt

Htp -(r)di(w)- nswt PtH n kA n nbt pr WADt

The offering which the king gives to the $k a$ of the mistress of the house Itut ${ }^{14}$

The offering which the king gives and Ptah to the ka of the mistress of the house Wadjet

$\mathrm{F}$ - in front of the son on the right side

$m$ ir $n$ sA $n$ it=f Inpw-nxt mAa $-x r w n b$ $\operatorname{imAx}$

${ }^{9}$ Franke, D.2002, "The Middle Kingdom Stelae publication project, exemplified by stela BM 226", in :BMSAES 1.p. 10.

${ }^{10}$ PN I,315,[18]

${ }^{11} \mathrm{PN}$ I,260[13]

${ }^{12}$ PN I,57 [7]

${ }^{13} \mathrm{PN}$ I, 264 [24]

${ }^{14} \mathrm{PN}$ I, 50 [11] short -wide kilt while a wide collar on his neck and scarf on his chest, next to him there are two ladies each one of them is standing wearing a long tight dress and smells a lotus flower, they wear a long hair wig, wide collar in blue color and bracelets on the hands and legs colored in blue.

Texts:

A-on top of the owner of the stela

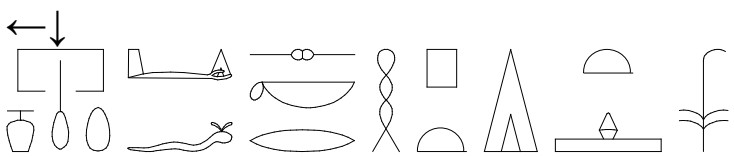

Line 1-

$\leftarrow \downarrow$

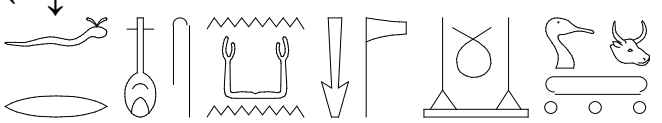

Line 2-

B-under the offering table

ए

C-on top of the wife of the owner stela and his son

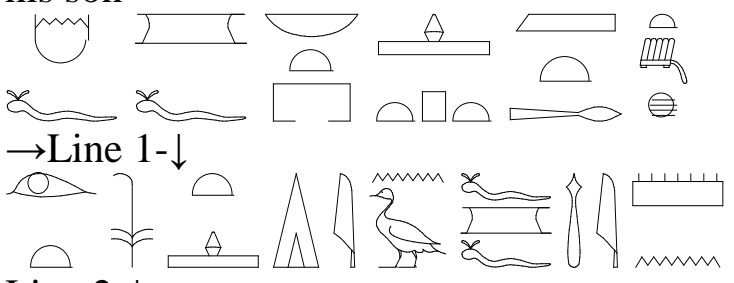

Line $2-\downarrow \rightarrow$

D- on top of the son on the left side

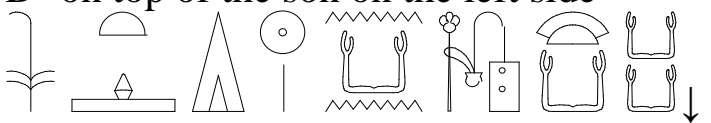

E- on top of the two ladies on the left side

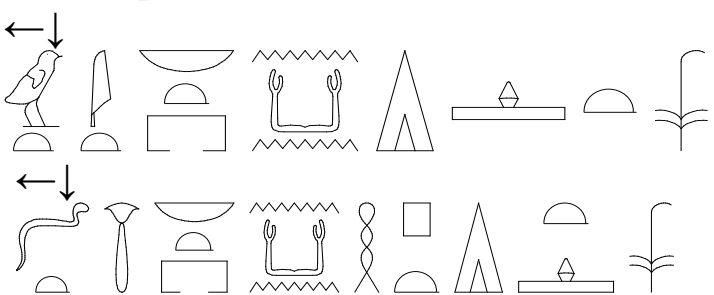

F- in front of the son on the right side

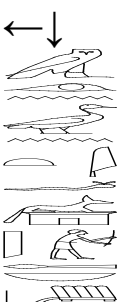

The transliteration and Translation

A-on top of the owner stela 
while it appeared on the tombs frmthe time of Senusert I. ${ }^{28}$

(c)The name of kha-kaw attested in many private names date back to the Middle Kingdom, it is an abbreviation of the name of king Senusert III (\#a-kAw-Ra) ${ }^{29}$,The holders of this name must have lived during the late Middle Kingdom during the time of Kings Senusert III and Amenemhat III, many officials hold this name like: the owner of the Stela CG20418 named KhaKaw from Abydos ${ }^{30}$, the owner of the Stela CG20715 named Kha-Kaw from Abydos ${ }^{31}$, other officials called Kha-kaw-Re khu niutef ${ }^{32}$,Kha-Kaw-Re Seneb, the owner of the stela CG20019 from Abydos ${ }^{33}$, KhaKaw-Re- em-ahet ${ }^{34}$ and finally Snefru KhaKaw-Re, the owner of the stela CG 20066 from Abydos ${ }^{35}$, those individuals in order to aspired to approach the terrace of the great god Osiris Khentyimentyu ${ }^{36}$, they erected chapels and stelae nearby the processional road and the cenotaphs dedicated at the site by the kings of the twelfth and thirteenth dynasties.

(d) the scribe may be wrote the word

m-ir.n in confusion with $m-r$ which means the overseer, if this true the suggested translation could be: $\mathrm{m}-\mathrm{r}$ sA $\mathrm{n}$ it=f Inpw-nxt mAa - xrw nb imAx " The Overseer, the son

\footnotetext{
${ }^{28}$ Fischer,H.G.1976. Varia Nova, Egyptian Studies I, New York, p.76

29 Von Becherath , J. 1984, Handbuch des ägyptischen königsnamen, MÄS 20, pp.198-199; Quirke,S.2010, Who Were the Pharaohs, A Guide to Their Names, Reigns and Dynasties, London,p.76
}

\footnotetext{
${ }^{30}$ Lange and Schäfer, Grab und Denksteine, I, p.19

31 Lange and Schäfer, Grab und Denksteine, II, pp.341-342; PN I, 265 [25]

${ }^{32} \mathrm{PN} \mathrm{I}, 265$ [1]

${ }^{33} \mathrm{PN}$ I, 265 [2]; Lange and Schäfer, Grab und Denksteine, I, pp.18-19

${ }^{34} \mathrm{PN}$ I, 265 [2]

35 PN I, 315 [17]; Lange and Schäfer, Grab und Denksteine, I, pp.81-82

${ }^{36}$ Simpson, W.K. 1974, The Terrace of the Great God at Abydos:The Offering Chapels of Dynasties 12 and 13, Philadelphia,pp.1-16; Von Becherath,J. in: $L \ddot{A} \mathrm{I}, \mathrm{col} .32$
}

That made by ${ }^{\left({ }^{())}\right.}$the son of his father Inpw-nekht ${ }^{15}$, the justified and the lord of reverence

\section{Comments}

(a) It was familiar by the time of second half of the Twelve Dynasty to form the stelae in the shape of a false door with a cornice on the upper part with reeds decoration such as: stela

CG20014 from Abydos $^{16}$, stela CG20231 from Abydos which has the cartouch of king Amenemhat $\mathrm{III}^{17}$, stela of Ptah Snefru CG 20686 it refers to the year 14 of the reign of Senusert III from Abydos ${ }^{18}$, stela CG20435 from unknown provenance $^{19}$, stela CG 20017 from Abydos $^{20}$, stela CG 20337from Abydos ${ }^{21}$, stela CG 20519 from Abydos ${ }^{22}$ and this type continued during the thirteenth dynasty such as: stela CG 20483 from Abydos $^{23}$, stela CG 20573 from Abydos ${ }^{24}$, stela CG 20690 from Abydos $^{25}$ and stela CG 20717 from Abydos . ${ }^{26}$

(b)The title $n b t-p r$ mistress of the house began to appear on stelae from the time of Senusert III and Amenemhat III ${ }^{27}$

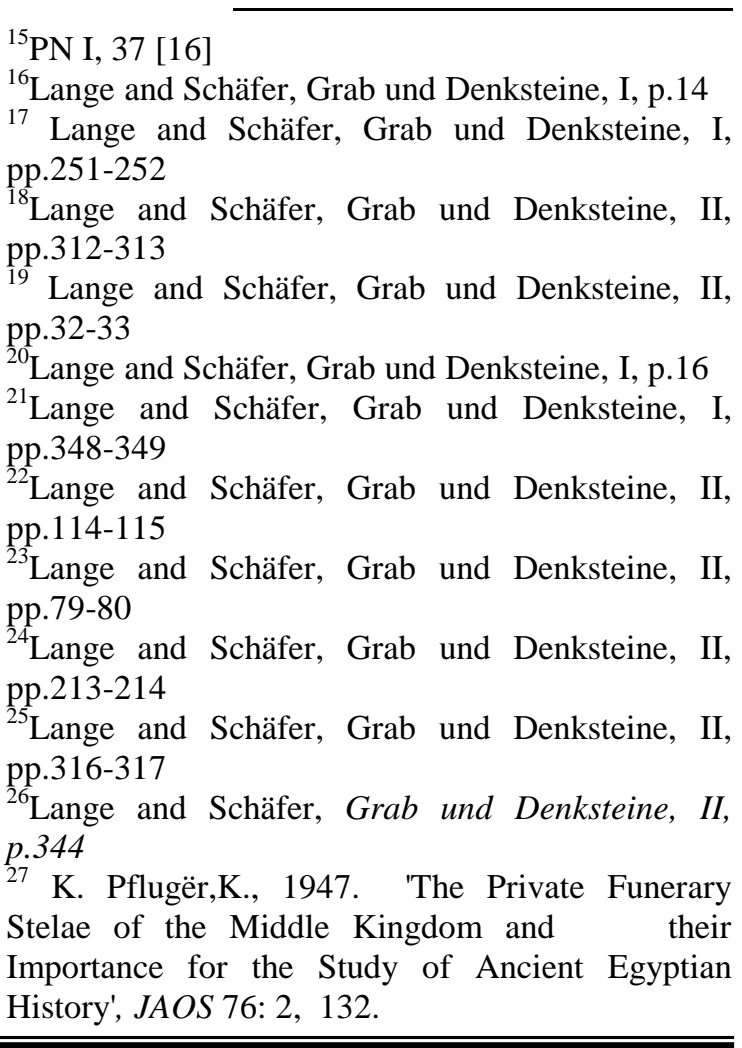

${ }^{16}$ Lange and Schäfer, Grab und Denksteine, I, p.14

17 Lange and Schäfer, Grab und Denksteine, I, pp.251-252

${ }^{18}$ Lange and Schäfer, Grab und Denksteine, II, pp.312-313

${ }^{19}$ Lange and Schäfer, Grab und Denksteine, II, pp.32-33

${ }^{20}$ Lange and Schäfer, Grab und Denksteine, I, p.16

${ }^{21}$ Lange and Schäfer, Grab und Denksteine, I, pp.348-349

${ }^{22}$ Lange and Schäfer, Grab und Denksteine, II, pp.114-115

Lange and Schäfer, Grab und Denksteine, II, pp.79-80 pp.213-214

${ }^{25}$ Lange and Schäfer, Grab und Denksteine, II, pp.316-317

${ }^{26}$ Lange and Schäfer, Grab und Denksteine, II, p.344

27 K. Pflugër,K., 1947. 'The Private Funerary Stelae of the Middle Kingdom and their Importance for the Study of Ancient Egyptian 
of (his) father Inepu-nekht, the justified,

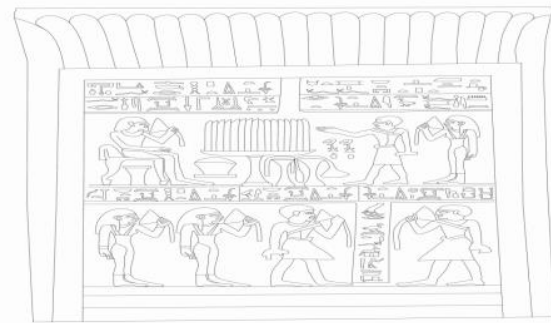

The Stela of Snerfer(u), facsimile by Mona Abady (C) Egyptian Museum, Cairo.

\section{Bibliography}

1. Baines, J. 1990.Recording the temple of Sethos I at Abydos in Egypt. Bulletin of the Ancient Orient Museum 11.

2. Baines, J. 2001. Colour use and the distribution of relief and painting in the Temple of Sety I at Abydos. In Davies, W. V. (ed.), Colour and painting in ancient Egypt, 145-157. London: British Museum Press.

3. Bestock, L. 2011. The first kings of Egypt: the Abydos evidence. In Teeter, Emily (ed.), Before the pyramids: the origins of Egyptian civilization, Chicago.

4. Brand, P. J. 2000. The monuments of Seti I: epigraphic, historical and art historical analysis. Probleme der Ägyptologie 16. Leiden: Brill.

5. Calverley, A.M. and Myrtle F. B. 1933-1958. The temple of king Sethos I at Abydos, 4volumes: I: the chapels of Osiris, Isis and Horus. II : the chapels of Amen-Rē', Re'-Harakhti, Ptah, and King Sethos. III: the Osiris complex. IV: the second hypostyle hall. London; Chicago: Egypt Exploration Society; University of Chicago Press.

6. Dreyer, G.2011.Tomb U-J: a royal burial of Dynasty 0 at Abydos. In Teeter, Emily (ed.), Before the pyramids: the origins of Egyptian civilization, Chicago.

7. Frankfort,H.1933. The cenotaph of Seti I at Abydos. 2 vols. London: Egypt Exploration Society. lord of reverence.

\section{Conclusion}

1-The owner of the stela is called Sneferu his wife is called Hetepet, his son is called Kha-Kaw, his daughter is called Itut, his second daughter is called Wadjet and his eldest son is the overseer Inpu-nekht who may be dedicated the stela for his father and family.

2- According to the typology and phraseology of the stela it could be dates back to the second half of the twelfth dynasty and beginning of the thirteenth dynasty.

3- The appearance of the ointment vessel under the chair of the owner of the stela is a feature of the late twelfth Dynasty

4- Smiling Lotus flowers by individuals became common during the end of the twelfth dynasty and through the thirteenth Dynasty

5- The wig of men which is known as Bag-wig is an indication of the twelfth Dynasty. ${ }^{37}$

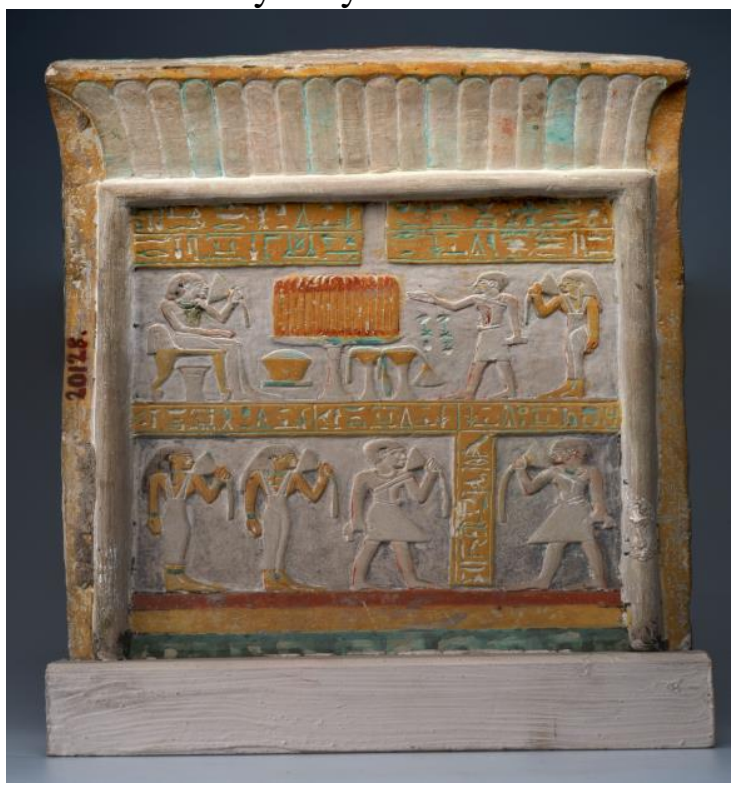

The Stela of Snerfer(u),photo by Ahmed Amin. (C) Egyptian Museum, Cairo.

${ }^{37}$ Leprohon,R.J. 1983, Stela I, The Early Dynastic period and Middle Kingdom, Cairo, pp.2,7,162. 
19. Peet, T. E. and Loat W. L. S. 1913. The cemeteries of Abydos. Part III: 1912-1913. Memoir of the Egypt Exploration Fund 35. London: Egypt Exploration Fund.

20. Petrie, W. M. F. 1900-1901. The royal tombs of the First Dynasty, 3 vols. Memoir of the Egypt Exploration Fund 18. London: Egypt Exploration Fund.

21. Petrie, W. M. F. Ayrton, E. R., Currelly, C. T. and Weigall, A. E. 1902-1904. Abydos, 3 vols. Memoir of the Egypt Exploration Fund 22; 24. London: Egypt Exploration Fund.

22. PM V = Porter, B.and Moss, L.B, 1962. Topographical Bibliography of Ancient Egyptian Hieroglyphic Texts, Reliefs and Paintings, V: Upper Egypt Sites, oxford .

23. PN I=Ranke, H.1935. Die Altägyptischen Personennamen, I ,Glückstadt.

24. Randall-MacIver, D. and Mace, A. C. 1902. El Amrah and Abydos, 18991901. London: Egypt Exploration Fund.

25. Sawy, Ahmed el- 2003.A new discovery at the Sety I temple in Abydos. In Hawass, Zahi and Lyla Pinch Brock (eds.), Egyptology at the dawn of the twenty-first century: proceedings of the Eighth International Congress of Egyptologists, Cairo, New York: American University in Cairo Press.

26. Snape, S. 1986.Mortuary assemblages from Abydos. D.Phil thesis, University of Liverpool; Von Beckerath,J.1975, "Abydos" in:LÄ I, Wiesbaden.

27. Stevenson, A.2009. The predynastic cemeteries of Abydos. Egyptian Archaeology 34.

28. Von Beckerath, J.1975. "Abydos" in: LÄ I, Wiesbaden.

29. Von Becherath , J. 1984. Handbuch des ägyptischen königsnamen, MÄS 20. Berlin.
8. Garstang, J.1901. El Arábah: a cemetery of the Middle Kingdom; survey of the Old Kingdom temenos, graffiti from the temple of Sety. British School of Archaeology in Egypt and Egyptian Research Account [6] (6th year), London.

9. Garstang, J.1909.Excavations at Abydos, 1909: preliminary description of the principal finds. Annals of Archeology and Anthropology 2.

10. Lange, H.O. and Schäfer, H. (190225) Grab und Denksteine des Mittleren Reiches, I-IV vols, (CCG Nos.20001-20780), Berlin.

11. Leprohon,R.J. 1983. Stela I, The Early Dynastic period and Middle Kingdom, Cairo.

12. Lieblein,J. 1892.Hieroglyphisches Namen-Wörterbuch, Leipzig.

13. Marriette, A. 1880.Abydos: description des fouilles: Temple de Séti (Supplément). Temple de Ramsès. Temple d'Osiris. Petit Temple de l'Ouest. Nécropole, Vol. II, Paris.

14. Marriette, A. 1880. Catalogue Generaldes Monuments d'Abydos decovert pendant les fouilles de cette ville, Vol. III, Paris.

15. Murray, M. A. 1904. The Osireion at Abydos. British School of Archaeology in Egypt and Egyptian Research Account [9] (9th year). London.

16. Naville, E.1914. The cemeteries of Abydos. Part I: 1909-1910. The mixed cemetery and Umm el-Ga'ab. Memoir of the Egypt Exploration Fund 33. London: Egypt Exploration Fund.

17. O'Connor, D. 2009. Abydos: Egypt's first pharaohs and the cult of Osiris. New aspects of antiquity. London.

18. Peet, T. E. 1914The cemeteries of Abydos. Part II: 1911-1912. Memoir of the Egypt Exploration Fund 34. London: Egypt Exploration Fund. 
